KAIROS ELT JOURNAL, Vol. 2, No. 3, December 2018

Copyright $\odot 2018$, ISSN: 2580-4278

\title{
IMPROVING STUDENTS' SPEAKING SKILL THROUGH PRESENTATION, PRACTICE AND PRODUCTION METHOD TO THE ELEVENTH GRADE STUDENTS OF SMA SWASTA KATOLIK BUDI MURNI 2 MEDAN
}

\author{
Fanta Elpin Gulo, Anna Stasya Prima Sari, Jontra J. Pangaribuan \\ Catholic University of Saint Thomas
}

\begin{abstract}
This research was conducted in order to improve students' speaking skill through Presentation, Practice and Production method to the eleventh grade students of SMA Swasta Katolik Budi Murni 2 Medan. In conducting this research, the writer used Classroom Action Research (CAR). This research showed that teaching speaking skill through Presentation, Practice and Production method to the eleventh grade students of SMA Swasta Katolik Budi Murni 2 Medan could improve their speaking skill. The result of the test showed that the students' mean score in pre-test is 58.37 with $5.71 \%$ of the students got score $\geq 75$, in formative test the mean score is 67.45 with $32.28 \%$ of the students got score $\geq 75$, and in post-test the mean score is 77.31 with $65.71 \%$ of the students got score $\geq 75$. The writer concluded that Presentation, Practice and Production method could improve the speaking skill of the eleventh grade students of SMA Swasta Katolik Budi Murni 2 Medan. On the other hand, the students' responses towards the method of the teaching sound good because above $80 \%$ of the students are interested, motivated and understand the lesson with the Presentation, Practice and Production method.
\end{abstract}

Keywords: Presentation, Practice and Production Method, Speaking Skill

\section{INTRODUCTION}

Many people are able to speak but difficult to write, because in nature language is spoken. In Indonesia English has been long taught formally, from kindergarten until university. In learning a language there are always four language skills to be achieved, they are listening, speaking, reading and writing. Actually all of English skills are important, but speaking skill is the most important skill that should be mastered by English learner since the goal of learning a language is speaking. One's speaking ability can describe how far the language learner mastered about the language itself. Speaking ability is challenging to master because speaking skill covers all of English elements. Turk (2003:20) states that spoken language is the first form of communication between human beings. From that statement it can be concluded that speaking is the first skill that should be taught first when someone learns about language and first goal of objective learning.

It is no wonder that English in Indonesia is a foreign language because it is limitedly used, just in the classroom, not outside the classroom. Therefore, speaking becomes something hard for the students to grasp. It is not only hard for them to study in the classroom, but also the environment does not help them after class. However, the teacher should take effort to help them speak thought limited in the classroom only.

Based on the experience of the writer when he did the internship program to the eleventh grade students of SMA Swasta Katolik Budi Murni 2 Medan in the Academic Year of 2017/2018 Class XI IPS 1, the writer found some problems in teaching and learning process of speaking skill. Firstly, the teacher hardly gives the students various activities, such as games, students' project, delivering speech, presentation and discussing some issues outside classroom activities. The class is monotonous and less fun. In addition, the students do not try to find out the materials by themselves to suffice or to accommodate their own needs in learning English. Secondly, the students' speaking skill is relatively low. They have difficulties in expressing ideas and opinions orally as they are afraid of making mistakes, lack of confidence to speak

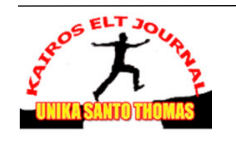


KAIROS ELT JOURNAL, Vol. 2, No. 3, December 2018

Copyright@2018, ISSN: 2580-4278

English. They still have difficulties in pronouncing certain English words, for examples: could, would, should, walking, talking, etc. To be able to speak, a large amount of vocabulary is also important, because without adequate vocabulary there is nothing to say. However, most students lack of vocabulary mastery and only few students in the classroom consult a dictionary. Their competencies in grammar are also poor. Therefore, they prefer to be silent and not fully participate in the classroom activities.

Considering the gap between the reality and expectation, the writer is interested in giving a probable solution. The writer is interested in proposing Presentation, Practice and Production (henceforth, PPP) method as a way out of the problem. PPP method is believed to be able to stimulate and guide the students to speak. PPP method is seen as an active learning process because the students will learn more through a process in constructing and creating knowledge, working in a group, explaining and demonstrating and also sharing knowledge to one another. It makes the students able to express their ideas and also make the learning process more interesting and entertaining.

The writer chooses this method because some research findings have shown the good results of teaching speaking by using PPP method. The first research was conducted by Lagalo (2013) entitled "The Application of Presentation, Practice and Production (PPP) Method to Increase Students' Speaking Skill (A Research Conducted at the Tenth Grade Students of MAN Batudaa in the Academic Year of 2012/2013)". The research findings showed that students' speaking skill improved after the patterns of PPP method was applied. The mean score of the students in the pretest is 48.87. After applying PPP method, the mean score of the students became 67.17 in post test cycle I and in the post test cycle II the mean score of the students became 77.83. She concluded that the application of the patterns of PPP method could make the students more active in the learning teaching process. The second one was conducted by Millah (2014) entitled “Improving the Students' Speaking Ability by Using PPP (Presentation, Practice and Production) Method to the Tenth Grade Students of MA NU Miftahul Falah Cendono Dawe Kudus in the Academic Year of 2013/2014”. The research findings showed that students' speaking skill improved after the patterns of PPP method was applied. The mean score of the students in the pretest is 54.03. After applying PPP method, the mean score of the students became 69.80 in post test cycle I and in the post test cycle II the mean score of the students became 75.81. She concluded that the implementation of the patterns of PPP method make the classroom interaction more enjoyable. The third one was conducted by Wati (2014) entitled "Improving the Eighth Grade Students' Speaking Achievement by Using Presentation, Practice and Production (PPP) Method at MTs Hidayatul Islam Krucil Probolinggo in the Academic Year of 2015/2016". The research findings showed that students' speaking skill improved after the patterns of PPP method was applied. The mean score of the students in the pretest is 52.86. After applying PPP method, the mean score of the students became 67.94 in post test cycle I and in the post test cycle II the mean score of the students became 74.12. She concluded that the using of PPP method make the students more interested, motivated and easier to understand.

Considering the findings of the previous researches, the writer is interested in applying PPP method to solve the speaking problems faced by the eleventh grade students of SMA Swasta Katolik Budi Murni 2 Medan in the Academic Year of 2017/2018 Class XI IPS 1. Based on the background of the study, the writer aroused to conduct a research entitled "Improving Students' Speaking Skill through Presentation, Practice and Production Method to the Eleventh Grade Students of SMA Swasta Katolik Budi Murni 2 Medan in the Academic Year of 2017/2018".

\section{REVIEW OF LITERATURE}

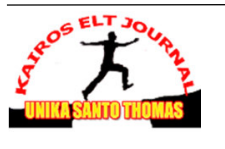


KAIROS ELT JOURNAL, Vol. 2, No. 3, December 2018

Copyright $\odot 2018$, ISSN: 2580-4278

\subsection{Speaking}

Speaking is an activity of delivering message occurs between speaker and listener orally. In other words, the main point of speaking activity is that speakers communicate their message to the listeners. In this case, the speaker and listener should be able to understand each other. The speaker can produce the sounds that involve the messages and the listener can receive, process, and response the messages. Brown (2007: 140) states that speaking as oral interaction which the participants need to negotiate meaning contain ideas, feeling and information. It could be said that the ability to speak is the reason for the people to communicate with other in order to tell people about something which they do not know, or to find something out from other people.

According to Caroline (2005: 45), speaking is a basic oral communication among people in society.It means speaking which serves as natural means of communication of the members of the community for both expression of thought and form a social behavior. In addition, Cameron (2001: 40) states that speaking is about making people understand speaker's feeling and ideas by doing an act of communication using language. Thus, speaking is not as simple as process of producing sounds but the fact speaking is more complex.

From the theories above, it can be concluded that speaking is an ability to express ideas, feelings and information to other person. The language is used to express oneself to be understood by others. Therefore speaking is a skill of transferring the idea to others in spoken language. It concerns with the use of language in daily activity in which people need to communicate with others to fulfill the need of socialization.

\subsection{Speaking Skill}

Speaking is skill that has to be mastered by students in learning English because the objective of learning a language is communication. Richards (2008:19) states, "In speaking we tend to be getting something done, exploring ideas, working out some aspects of the world, or simply being together". Speaking English well also helps students to access up to date information in fields including science, technology and health. The students have to master all components of speaking skill in order to speak clearly and fluently. According to Fulcher and Davidson (2006:

94), there are five components of speaking skill that can be defined as follows:

1) Pronunciation: Pronunciation is the way for students to produce clearer language when they are speaking. It means that the student can communicate effectively when they have good pronunciation and intonation even though they have limited vocabulary and grammar. Pronunciation refers to the traditional or customary utterance of words.

2) Grammar: Grammar is needed for the students to arrange correct sentences in conversation both in written and oral forms. Grammar is defined as a systematic way of accounting for and predicting an ideal speaker's or hearer's knowledge of the language. This is done by a set of rules or principles that can be used to generate all well-formed or grammatical utterances in the language. Thus from statement above can be concluded that grammar is a rule that is needed for the students to combine correct sentences in conversation both in written and oral forms.

3) Vocabulary: Vocabulary is essential for successful second language use. Without an extensive vocabulary, we will be unable to use the structure and function we may have learnt for comprehending the communication. It can be said that one key the success in communicative, which is the power of $x$ rnrds It means that in spoken language or speaking, the vocabulary used must be very fan $7 \quad d$ it is used in everyday conversation in order to understand the spoken. Vocabula ${ }_{y}$ is we knowledge of meanings of words. What complicates this definition is the fact that words come in at least two forms: oral and written. Oral vocabulary is the set of words for which we know the meanings when we speak or read orally. Written vocabulary consists of those words for which the meaning is known when

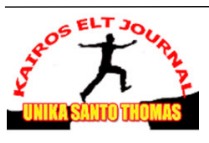


KAIROS ELT JOURNAL, Vol. 2, No. 3, December 2018

Copyright $\odot 2018$, ISSN: 2580-4278

the writing activities. These are important distinctions because the set of words that beginning readers know are mainly oral representations. As they learn to read, written vocabulary comes to play an increasingly larger role in literacy than does the oral vocabulary.

4) Fluency: Fluency is defined as the ability to speak communicatively, fluently and accurately. Fluency usually refers to express oral language freely without interruption. In teaching and learning process, if the teacher wants to check students' fluency, the teacher allows students to express themselves freely without interruption. The aim is to help students speak fluently and with ease. The teacher does not correct immediately whereas the idea being that too much correction interferes with the flow of conversation.

5) Comprehension: Comprehension is an ability to perceive and process stretches of discourse, to formulate representations the meaning of sentences. Comprehension of a second language is more difficult to study since it is not directly observable and must be inferred from verbal and non verbal responses, by artificial instruments or by the intuition of the teacher or researcher. Therefore, in speaking can be concluded that the comprehension refers to the speakers' understanding about what are they saying to the listeners in order avoid misunderstanding information.

\subsection{Elements of Speaking}

According to Harmer (2007: 263-264), there are many elements of speaking that must be mastered by students in order to be a good speaker. They are:

1) Connected speech: Effective speaker of English need to be able not only to produce the individual phonemes of English, but also to use connected speech fluently. In connecting speech, sounds are modified, omitted, added, or weakened. Example: I must go (aim Asgou), I have done it (aivdAn it), Last night (1Asnait).

2) Expressive devices: Native of Language change the pitch and stress of particular parts of utterances, vary volume and speed, and show other physical and non verbal means how they are feeling. The use of these devices contributes to the ability to convey the meaning.

3) Lexis and grammar: Therefore supply a variety of phrases for different functions such as agreeing or disagreeing, (I think so, yes of course), expressing surprise ( I am surprised, I do not believed it) or approval ( I allow you to).

\subsection{Teaching Speaking}

Speaking is a crucial part of second language learning and teaching. Despite its importance, for many years, teaching speaking has been undervalued and English language teachers have continued to teach speaking as repetitions of drills or memorization of dialogues. Teachers also should improve students' communicative in speaking, because in that way, students could express themselves and confidence learn how to follow the social and context appropriate in communication. According to Nunan (2004:89), there are some formulations that can be applied in teaching speaking. They are:

1) Produce the English speech sounds and sound patterns,

2) Use word and sentence stress, intonation patterns and the rhythm of the second language,

3) Select appropriate words and sentences according to the proper social setting, audience, situation and subject matter,

4) Organize their thoughts in a meaningful and logical sequence,

5) Use language as a means of expressing values and judgments, and

6) Use the language quickly and confidently with few unnatural pauses, which are called as fluency.

Thus, in teaching speaking, the teacher needs to use relevant and engaging material to increase students' self esteem and to make them conscious of their need for identity.

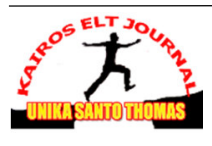


KAIROS ELT JOURNAL, Vol. 2, No. 3, December 2018

Copyright $\subseteq 2018$, ISSN: 2580-4278

\subsection{Types of Classroom Speaking Performances}

In teaching speaking, interpersonal and transactional dialogues should be included in an interactive classroom. The speaking performance has some levels starting from the simplest performance up to the highest one. According to Brown (2007: 271-274), there are six categories of classroom speaking performance. They are:

1) Imitative: This category goes for the ability of the students to copy some part of language not for the purpose of meaningful interaction but for focusing on some particular elements of language form.

2) Intensive: This category goes one step beyond imitative to include any speaking performance that is designed to practice some phonological or grammatical aspects of language.

3) Responsive: This category deals with students' speech in the classroom. It is including short replies to teacher or student-initiated questions or comments.

4) Transactional: Transactional language is carried out for the purpose of conveying or exchanging specific information. It is an extended form of responsive language.

5) Interpersonal: Interpersonal language carried out more for the purpose of maintaining social relationship than for the transmission of facts and information.

6) Extensive (monologue): This category is commonly found in the students at intermediate to advanced levels, they are asked to give extended monologues in the form of oral reports, summaries, or perhaps short speeches.

In this research, the writer is going to do extensive (monologue) types of speaking performances in which the students present their ideas about the topic that is chosen by the teacher.

\subsection{Methods in Teaching Speaking}

In teaching speaking, teachers should be able to apply a suitable method and technique in class, so that the teaching learning can be successful and the students are able to speak well. In achieving goals in teaching, teacher has to use various tools of instructional. According to Elizabeth (2004: 52-56), there are some methods in teaching speaking skill. They are:

1) Translation method is better known as Grammar Translation Method. In the teaching of English as a foreign language, it has enjoyed a great reputation in the past. Translation method means teaching the target language by translating it into mother tongue.

2) Direct method of teaching English means teaching English directly through English medium. In this method, mother tongue is not used at all. This method came as a reaction against the translation method. It is also called the natural method of teaching.

3) Bilingual method means where two languages i.e., the mother tongue and target language is used. Here the mother tongue is used to achieve the target language. This method is based on the similarities and differences which exist between the two languages.

From the explanations above it can be concluded that different set of learners need different methods that suits best to their requirements. If we closely analyze, we find that each methods has its own significance in its own right.

\subsection{Presentation, Practice, Production Method}

Presentation, Practice and Production or PPP is a method that the teachers present the context and situation for learning by explaining and demonstrating. Students then practice the language within controlled parameters including language drills. Finally students are allowed to be free with the language and encouraged to be creative and explorative. Nunan (1997: 36) states that Presentation, Practice and Production is relatively straight forward and structured enough to be easily understood by both students and new emerging teachers. Thus, this method makes the teacher easier to understand the material to the students.

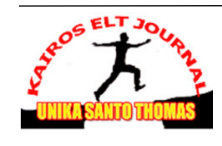


KAIROS ELT JOURNAL, Vol. 2, No. 3, December 2018

Copyright@2018, ISSN: 2580-4278

Furthermore, According to Harmer (2009:92), Presentation, Practice and Production or PPP method is a variation of audiolingualism and a traditional method of teaching. As its name suggests, PPP is divided into three phases, moving from tight teacher control towards greater learner freedom. Presentation refers to the introduction to a new subject or lesson. It requires creating a realistic situation in which the target language would be taught and acquired. Usually, this is done through using pictures, dialogues and actual classroom situations. Practice refers to the students practice the target language in one or three activities that progress from very structured to less structured. These activities should include as much "student talk" as possible and not focus on written activities, though written activities can provide a structure for the verbal practices. Production is the stage of the lesson where the students take the target language and use it in conversations and use it to talk about themselves or their daily lives or situations.

\subsubsection{Procedures of Applying PPP Method}

According to Harmer (2007: 65-66), there are three procedures of applying PPP method. They are:

1) Presentation: The process of presenting the lesson focuses on teacher giving information to the students. The goal of presentation is to introduce the new material to the learners by short and simple explanations, a brief description of the new topic, idea, pictures, video, music, and demonstrations acting. For example: the teacher explains one topic about descriptive text.

2) Practice: The practice process is focused on teacher and students working and interacting together to put the new material into practice. The students will be given an activity that gives them plenty of opportunities to practice the new aspect of language and become familiar with it whilst receiving limited an appropriate assistance from the teacher. The students repeat the sentence individually and the teacher corrects any mistakes that he hears by doing brainstorming, question and answer, comprehension exercises, and games. For example: the teacher point one by one of the students to check their learning,

Teacher: Andrew, repeat this sentence after me "He is swimming in chorus"

Students: "He is swimming in chorus"

Teacher: Good, Andrew.

3) Production: Production focuses on students demonstrating their ability to the teacher. The teacher can observe what the individual students have learned and which student need additional support. In this process, the teachers are receiving information and indirectly students' mistakes, monitoring the students as they complete exercises that enable them to demonstrate comprehension without giving the answer. For example: the teacher may get the students to imagine that they are all in holiday. They must say what each of them does.

By applying PPP method, the students would get opportunities to share their ideas and make themselves confident to speak through PPP method. Therefore, the students' speaking skill can improve as well as possible.

\section{RESEARCH METHOD}

This research is Classroom Action Research (CAR). According to Burns (2010: 2), action research is related to the ideas of "reflective practice" and "the teacher as researcher" involves taking a self-reflective, critical, and systematic approach to exploring your own teaching context. In other words, action research is defined to solve the problems through direct application in the classroom and improving outcomes of teaching and learning. Moreover, Nunan (1997: 18) states that action research has distinctive feature that is those affected by planned changes have the primary responsibility for deciding on courses of critically informed action which seem likely to improve for evaluating the results of strategies tried out in practice.

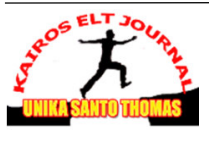


KAIROS ELT JOURNAL, Vol. 2, No. 3, December 2018

Copyright@2018, ISSN: 2580-4278

It means that, through the classroom action research, the teacher will know the problem that students face in learning when the teacher gives treatment to the students and evaluate their achievement in learning. From the definitions above, the writer can conclude that classroom action research is an action research in a classroom which can be done by teachers, researchers, and teachers with their colleagues, etc which involves a group of students to improve teaching and learning process or to enhance the understanding of the students to the lesson.

\section{RESEARCH FINDING AND DISCUSSION}

\subsection{Research Finding}

The finding of this research showed that PPP method could improve students' speaking skill. The improvement could be seen from the students' mean score from the pre-test until post-test. The students' mean score in pre-test is 58.37 , the mean score of formative test is 67.45 and the mean score of post-test 77.31. The qualitative data also showed that students became more active, enthusiastic, and eager in practicing speaking in the English language.

\subsection{Discussion}

PPP method was applied to improve students' speaking skill to the eleventh grade students of SMA Swasta Katolik Budi Murni 2 Medan. Before applying PPP method in teaching speaking the writer analyzed the most of the students did not pay attention to their teacher. The result of the pre-test also showed that the students' score were not satisfying. Only 2 students of 35 students passed the KKM.

This research has proved that PPP method is effective to improve students' speaking skill. It is shown in the students' score from pre-test, formative test until post-test. The students' pronunciation, fluency, accuracy, and vocabulary in speaking improved after PPP method was applied in learning teaching processes. It happens because this method challenges students to speak up more and share their ideas about topics chosen by the writer in every meeting in cycle 1 and cycle 2. Students were also given corrections by the writer at the end of leaning teaching process so that they knew their mistakes in pronouncing some words while speaking up. It was because the writer controlled the class better, directly gave advice to the students who did not pay attention in learning teaching process.

\section{CONCLUSIONS AND SUGGESTIONS 5.1 Conclusions}

After analyzing and discussing the data, the writer draws the following conclusions as follows:

1. PPP method could improve students' achievement in increased students' speaking skill. The students' mean score of pre-test is 58.37 , formative test is 64.75 and post-test is 77.31 . Meanwhile, the students score percentage who passed Mastery Minimum Criteria (Kriteria Ketuntasan Minimum) from pre-test is $5.71 \%$, the formative test is $32.28 \%$ and post-test is $65.71 \%$. The students' score and percentage continuously increased each test. Therefore, it is concluded that PPP method could improve students' achievement in speaking skill.

2. PPP method is a new method for the students but after being taught with PPP method the responses of the students are good. The students' responses towards the method of the teaching sound good because above $80 \%$ of the students are interested, motivated and understand the lesson. The students were trained to speak in the English language when PPP method was being applied in speaking skill even though some of the students felt shy and still nervous but they did not stop speaking in English. It seems that this method is beneficial to the students because their speaking skill can improve significantly after Presentation, Practice and Production method was applied to teach speaking skill.

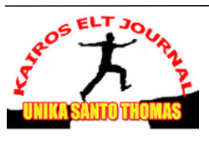


KAIROS ELT JOURNAL, Vol. 2, No. 3, December 2018

Copyright $C 2018$, ISSN: $2580-4278$

\subsection{Suggestions}

In the relation to the conclusions above, there are some suggestions that can be given by the writer to:

1. the teacher should be more creative in applying PPP method in order to maximize teaching speaking skill. Thus, the students become active and interested in learning English, especially in learning speaking skill,

2. the students should pay attention to the rules how to improve their speaking skill through the application of PPP method,

3. other researchers, the result of this study is expected to be able to provide them valuable information about how to improve students' speaking skill through the application PPP method.

\section{BIBLIOGRAPHY}

Brown, H. 2007. Principles of Language Teaching and Learning (Fifth Edition). New York: Pearson Longman.

Burns, A. 2010. Doing Action Research in English Language Teaching: A Guide for Practitioners. New York: Routledge.

Cameron, L. 2001. Teaching Languages to Young Learners. Cambridge: Cambridge University Press.

Caroline, T. 2005. Practical English Language Teaching Young Learners. New York: Mc. Graw-Hill.

Elizabeth, M. E. S. 2004. Methods of Teaching English. New Delhi: Discovery Publishing House.

Fulcher, G., \& Davidson, F. 2006. Language Testing and Assessment: An Advanced Resource Book. New York: Routledge.

Harmer, J. 2007. The Practice of Language Teaching (Fourth Edition). London: Longman. . 2009. How to Teach English (Fifth Edition). Harlow: Longman.

Kemmis., \& McTaggart, R. 1997. Participatory Action Research: International Context and Consequences. New York: State University of New York.

Lagalo, A. M. S. 2013. The Application of Presentation, Practice and Production (PPP) Method to Increase Students' Speaking Skill (A Research Conducted at the Tenth Grade Students' of MAN Batudaa in the Academic Year of 2012/2013). An Unpublished Sarjana's Thesis, Faculty of Letters and Culture: State University of Gorontalo.

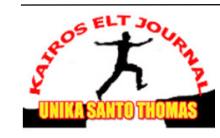


KAIROS ELT JOURNAL, Vol. 2, No. 3, December 2018

Copyright $\odot 2018$, ISSN: 2580-4278

Millah, F. N. H. 2014. Improving the Students' Speaking Ability by Using PPP (Presentation, Practice and Production) Method to the Tenth Grade Students of MA NU Miftahul Falah Cendono Dawe Kudus in the Academic Year of 2013/2014. An Unpublished Sarjana's Thesis, Teachers Training and Education Faculty: Muria Kudus University.

Nunan, D. 1997. Research Methods in Language Learning. Cambridge: Cambridge University Press.

.2004. Research Methods in Language Teaching. Cambridge: Cambridge University Press.

O’Malley, J. M., \& Pierce, L. V. 1990. Authentic Assessment for English Language Learner: Practical Approach for Teacher. Massachusetts: Addison Wesley.

Richards, J. 2008. Teaching Listening and Speaking from Theory to Practice. Cambridge: Cambridge University Press.

Thomas, R. M. 2003. Blending Qualitative and Quantitative Research Methods in Theses and Dissertations. California: Corwin Press.

Turk, C. 2003. Effective Speaking: Communicating in Speech. London: Spon Press.

Wati, R. 2014. Improving the Eighth Grade Students' Speaking Achievement by Using Presentation, Practice and Production (PPP) Method at MTs Hidayatul Islam Krucil Probolinggo in the Academic Year of 2015/2016. An Unpublished Sarjana's Thesis, Faculty of Teachers Training and Education: Muhammadiyah University of Jember. 